\title{
PENGARUH PEMBERIAN KAPSUL EKSTRAK GARLIK TERHADAP PERUBAHAN TEKANAN DARAH DAN JUMLAH TROMBOSIT PADA PENDERITA PREEKLAMPSI RINGAN
}

\section{(THE EFFECT OF EXTRACT GARLIC CAPSULE TOWARD THE CHANGES OF BLOOD PRESSURE AND THROMBOCYT LEVEL IN THE MILD-PREECLAMPSY PATIENTS)}

\author{
Yahya Irwanto, Imam Wahyudi, Soetomo Soewarto \\ Sub Bagian Fetomaternal SMF Obstetri dan Ginekologi FK Unibraw/ RSU Dr. Saiful Anwar Malang
}

\begin{abstract}
The objectives is to investigate the efectivity of extract garlic capsule compared to standart therapy toward the changes of blood presure and thrombocyt level in the mild-preeclampsy patients. This study was a single-blind randomised clinical trial. The subject of study were the mild-preeclampsy pregnant women within 20 - 36 weeks of gestational age whose came to the Poli Hamil RSUD dr. Saiful Anwar. The subject divided into 2 groups, the treatment group received both of the standart therapy of mild-preeclampsy and extract garlic capsule, while the controlling group only received the standart therapy of mild-preeclampsy. After 2 weeks, the blood pressure and the trombocyt count was evaluated. The systolic blood pressure of the treatment group was decrease at average of $10.12 \mathrm{mmHg}$, from $140.25 \pm 5.57$ before treatment to $130.12 \pm 10.84 \mathrm{mmHg}$ after treatment, while in the contrololling group there was an increase at average of $5.56 \mathrm{mmHg}$ from $140.44 \pm 6.14 \mathrm{mmHg}$ to $146 \pm 13.81 \mathrm{mmHg}$. The $T$ Test and ANCOVA analyzing showed a significant result ( $P$ value were 0.001 and 0.0008 ). There was also a significant decrease in diastolic blood pressure for the treatment group with the average of $9.06 \mathrm{mmHg}$ from $92.5 \pm 5.52 \mathrm{mmHg}$ before treatment to $83.44 \pm 7.69 \mathrm{mmHg}$ after treatment, while for the controlling group thre was an increase at average of $4.19 \mathrm{mmHg}$ from $92.94 \pm 4.77 \mathrm{mmHg}$ to $97.13 \pm 10.01 \mathrm{mmHg}$ ( $P$ value were 0.000 and 0.000 using T Test and ANCOVA analyzing). There was no significance changes for the thrombocyte count for both of groups, the average decrease of the treatment group was $2.175 \%$ while the averege decrease of the controlling group was $5.216 \%$ ( $P$ value for $T$ Test was 0.373 and for ANCOVA was 0.601). The consumption of extract garlic capsule for two weeks can give a significance changes of decreasing the systolic and diastolic blood pressure in the mild-preeclampsy pregnant women, but not of thrombocyte count.
\end{abstract}

Key words: extract garlic, mild-preeclampsy, systolic, diastolic, thrombocyte

\section{PENDAHULUAN}

Preeklampsi merupakan salah satu komplikasi kehamilan yang sampai saat ini penyebabnya masih belum diketahui dengan pasti. Saat ini ada 4 hipotesa tentang etiologi dan patogenesa dari preeklampsi yang terus dikaji secara luas oleh para ahli yaitu: iskemia placenta, Veri low-density lipoprotein versus toxicitypreventing activity, maladaptasi imunologis dan faktor genetik (1).

Dari berbagai teori tentang etiologi dan patofisiologi preeklampsi sebagian besar akhirnya bermuara pada terjadinya gangguan fungsi endothel. Penelitian pada dekade terakhir banyak menunjukkan bahwa disfungsi endothel merupakan komponen penting dari patofisiologi terjadinya preeklampsi seperti peningkatan fibrinectin seluler, VCAM-1, Growth factor, dan factor VIII antigen serta peningkatan peptida akibat cedera endothel meningkat mendahului gejala klinis pada preeklampsi. Mediator lain yang dihasilkan oleh endothel adalah NO (nitric oxide), dimana bersama prostasiklin sebagai vasodilator lokal dan anti agregasi platelet. Produksi NO menurun pada keadaan cedera endothel, dan juga terjadi penurunan ekskresi NO pada urine pasien preeklampsi $(1,2,3,4)$.

Bawang putih dalam bahasa latin dikenal sebagai allium sativum atau garlic merupakan tumbuhan yang berasal dari famili

Jurnal Kedokteran Brawijaya, Vol. XX, No.3, Desember 2004 Korespondensi: Soewarto S; Sub Bagian Fetomaternal SMF Obstetri dan Ginekologi FK Unibraw; Jl. Veteran Malang-65145; telp (0341) 580993, 567192 fax (0341)564755. liliace, penggunaannya telah dikenal sejak 5000 tahun yang lalu. Kandungan kimia dari bawang putih pertama kali dikenal pada tahun 1844 saat Theodor Wertheim melakukan ekstraksi substansi minyak dari bawang putih dengan bau menyengat yang dinamakan allyl-sulfur. Walaupun berbagai komponen aktif dari bawang putih telah berhasil diidentifikasi, para ahli percaya bahwa masih banyak lagi komponen bawang putih yang belum dapat diidentifikasi. Beberapa manfaat medis dari bawang putih yang telah dikenal dan sudah dibuktikan dengan penelitian adalah antibiotik, anti jamur, anti oksidan, anti kholesterol, anti hipertensi, imunomodulator, anti atherosklerosis, dan anti agregasi platelet. Atas dasar efek bawang putih yang dapat berperan sebagai anti oksidan, anti hipertensi, dan anti agregasi platelet dengan cara menghambat sintesa tromboksan dan aktivasi dari enzim notric oxide sinthase maka sesuai dengan patofisiologi, penggunaan bawang putih sebagai obat preeklampsi mendapatkan dasar yang cukup kuat $(5,6,7,8,9)$.

Pada peneliltian ini akan dilihat pengaruh dari pemberian tablet ekstrak bawang putih terhadap penurunan tekanan darah dan jumlah trombosit penderita preeklampsi ringan, dimana penderitanya diambil dari pasien yang berkunjung ke poli hamil RSSA. Kapsul

\section{METODE}

\section{Rancangan Penelitian}

Rancangan penelitian ini adalah prospektif dengan uji klinis tersamar tunggal (single blind randomized control trial). 
Irwanto, dkk., Pengaruh Pemberian Kapsul Ekstrak Garlik ....... 155

Populasi penelitian

Populasi penelitian adalah wanita hamil dengan preeklampsi ringan yang datang di poli hamil RSUD Dr. Saiful Anwar Malang.

\section{Besar sampel}

Besar sampel adalah 16, dengan tingkat kepercayaaan 95\% dan tingkat signifikansi 0,05

\section{Kriteria inklusi}

- PER (Preeklamsia Ringan)

- Janin tunggal, hidup

\section{Kriteria eksklusi}

- Kehamilan dengan riwayat penyakit DM, HT kronis, gemelli, dan peny. Ginjal

- Penderita menolak ikut dalam penelitian ini

\section{Analisa statistik}

Data yang terkumpul diolah dengan perangkat SPSS-11 dan dilakukan uji T maupun analisa ANCOVA

\section{HASIL PENELITIAN}

Tabel 1. Karakteristik Subyek Penelitian

\begin{tabular}{|c|c|c|c|c|}
\hline Variabel & $\begin{array}{c}\text { Kelompok kontrol } \\
(\mathbf{n}=\mathbf{1 6})\end{array}$ & $\begin{array}{c}\text { Kelompok Penelitian } \\
(\mathbf{n}=16)\end{array}$ & Sig. & Ket. \\
\hline Umur & $26 \pm 3.3$ & $27 \pm 4.8$ & 0.825 & NS \\
\hline Usia hamil & $29.5 \pm 4.3$ & $28.6 \pm 3.8$ & 0.742 & NS \\
\hline Berat badan & $68.419 \pm 5.555$ & $65.194 \pm 10.66$ & 0.976 & NS \\
\hline Paritas & $1.35 \pm 0.72$ & $1.45 \pm 0.93$ & 0.637 & NS \\
\hline Sistole & $140.44 \pm 6.14$ & $140.25 \pm 5.57$ & 0.101 & NS \\
\hline Diastole & $92.94 \pm 4.77$ & $92.50 \pm 5.25$ & 0.087 & NS \\
\hline Trombosit & $269831 \pm 37012.10$ & $261500+61923.61$ & 0.001 & S \\
\hline PCV & $33.413 \pm 3.66$ & $31.462 \pm 3.951$ & 0.135 & NS \\
\hline
\end{tabular}

Dari berbagai variabel tampak bahwa pada kedua kelompok penelitian, kondisi sebelum dilakukan perlakuan tidak berbeda bermakna kecuali pada kadar trombosit dimana didapatkan perbedaan yang bermakna antara kedua kelompok penelitian.

Tabel 2. T- tes Perubahan Variabel Sístole, Diástole, Trombosis, Berat Badan, PCV Sebelum dan Setelah Penelitian

\begin{tabular}{|c|c|c|c|c|}
\hline Variabel & Kontrol & Perlakuan & Sig. & Ket. \\
\hline Sistole & $5.5625 \pm 13.267$ & $-10.125 \pm 10.164$ & 0.001 & S \\
\hline Diastole & $4.1875 \pm 9.642$ & $-9.0625 \pm 7.2798$ & 0.000 & S \\
\hline Trombosit & $-14075 \pm 26690.01$ & $-5687 \pm 25764.88$ & 0.373 & NS \\
\hline Berat Badan & $0.900 \pm 0.9048$ & $0.3875 \pm 1.6128$ & 0.276 & NS \\
\hline PCV & $1.619 \pm 2.096$ & $-0.150 \pm 1.523$ & 0.011 & S \\
\hline
\end{tabular}

Hasil uji sampel secara independen dengan T-test menunjukkan adanya perbedaan bermakna antara kelompok perlakuan dan kontrol pada variabel sistole, diastole serta PCV, sedangkan perubahan trombosit dan berat badan tidak bermakna antara kedua kelompok penelitian.
Tabel 3. Hasil Analisis Covarian (ANCOVA) Dua Kelompok Penelitian Dengan Memperhitungkan Variabel Perancu

\begin{tabular}{|c|c|c|c|c|c|}
\hline Variabel & Kelompok & Rerata & SD & Sig & Ket \\
\hline \multirow{2}{*}{ Sistole post } & Kontrol & 146.00 & 13.81 & \multirow{2}{*}{0.008} & \\
\hline & Perlakuan & 130.12 & 10.84 & & \\
\hline \multirow{2}{*}{ Diastole post } & Kontrol & 97.13 & 10.01 & \multirow{2}{*}{0.003} & \\
\hline & Perlakuan & 83.44 & 7.69 & & \\
\hline $\begin{array}{l}\text { Trombosit } \\
\text { post }\end{array}$ & $\begin{array}{c}\text { Kontrol } \\
\text { Perlakuan }\end{array}$ & $\begin{array}{l}255756.25 \\
255812.50\end{array}$ & $\begin{array}{l}27744.62 \\
64194.72\end{array}$ & 0.601 & \\
\hline
\end{tabular}

Untuk mengetahui efek perlakuan terhadap tekanan darah dan jumlah trombosit pada keadaan terdapat variabel perancu (confounding variabel) digunakan ANCOVA (Analysis of Covariance) dimana hasilnya menunjukkan bahwa perlakuan berpengaruh bermakna terhadap sistole, diastole dengan $p$-value berturut-turut adalah 0.008 dan 0.003 , sedangkan efeknya terhadap trombosit adalah tidak bermakna ( $p$ value $=0.601$ ).

\section{DISKUSI}

Dari literatur yang ada dikatakan bahwa mekanisme garlik dalam menurunkan tekanan darah diperankan oleh allicin dan ajoene yang keduanya mempunyai efek relaksasi otot polos pembuluh darah. Secara invitro allicin dalam 15 menit menyebabkan hiperpolarisasi dari memban otot polos pembuluh darah sebesar $5,1 \mathrm{mV}$ dan berakibat berkurangnya tahanan pembuluh darah menjadi $24 \%$ dari tonus awal. Sedangkan ajoene menyebabkan hiperpolarisasi membran sebesar 4,4 mV yang menyebabkan efek relaksasi dan berkurangnya tonus pembuluh darah menjadi $11 \%$ dari tonus awal. Hiperpolarisasi terjadi karena ada peningkatan pembukaan K-channel. Adanya hiperpolarisasi tersebut menyebabkan peningkatan aliran $\mathrm{Ca}^{2+}$ kedalam otot vaskuler berkurang sehingga kadar kalsium intra seluler menurun dan terjadi vasodilatasi. Mekanisme yang lain adalah dengan jalan meningkatkan NO synthase sehingga kadar NO meningkat $(6,9,10)$.

Pada penelitian ini didapatkan penurunan tekanan darah sistolik dengan rerata $10,125 \mathrm{mmHg}$, sedangkan pada kelompok kontrol terjadi kenaikan dengan rerata $5,562 \mathrm{mmHg}$. Dengan uji T didapatkan perbedaan yang bermakna dengan $P$ value 0,001 , sedangkan dengan analisa ANCOVA didapatkan $P$ value 0,008 . Pengaruh pada tekanan darah diastole, didapatkan penurunan dengan rerata $9,06 \mathrm{mmHg}$ pada kelompok perlakukan sedangkan pada kelompok kontrol didapatkan kenaikan dengan rerata 4,18 $\mathrm{mmHg}$. Dengan uji $\mathrm{T}$ didapatkan perbedaan yang bermakna dengan $P$ value 0,000 sedangkan dengan analisa ANCOVA didapatkan $P$ value 0,000 . Hasil tersebut konsisten dengan penelitian sebelumnya yang dilakukan oleh Neill dkk dimana dapatkan penurunan tekanan sistolik rata-rata $7,7 \mathrm{mmHg}$ dan penurunan tekanan distolik rata-rata $5 \mathrm{mmHg}(10)$. Sedangkan Meiza dengan pre dan post test design didapatkan penurunan tekanan sistolik rata-rata $15,5 \mathrm{mmHg}$, dan penurunan tekanan diastolik rata-rata $11 \mathrm{mmHg}(6)$.

Penelitian Soranna dkk menunjukkan bahwa garlik dapat memotong resiko terjadinya preeklampsia dan juga meningkatkan berat badan janin pada kasus-kasus dengan resiko gangguan pertumbuhan janin (IUGR) (7). Soranna dkk juga menemukan 
bahwa pemberian ekstrak garlik pada trimester pertama kehamilan dapat menurunkan Resistensi Index (RI) dan Pulsatile Index (PI) dari arteri uterina sehingga aliran darah yang menuju uterus akan meningkat $(7,8,11,12)$.

Dari berbagai literatur yang ada, garlik diketahui mempunyai efek anti platelet agregasi dengan cara mempengaruhi sintesa tromboksan yang diperantarai enzim siklooksigenase. Sedangkan pada preeklampsi, terjadi stress oksidatif yang mengakibatkan terjadinya perubahan kearah prokoagulan sehingga akan terjadi peningkatan konsumsi trombosit yang berakibat penurunan jumlah trombosit $(13,14,15)$.

Pada penelitian ini antara kelompok perlakuan dan kelompok kontrol tidak ada perbedaan penurunan yang bermakna didapatkan $P$ value 0,73 . Hal ini kemungkinan disebabkan karena penderita pada penelitian ini adalah preeklampsi ringan dimana belum terjadi penurunan jumlah trombosit yang berat dibandingkan pada penderita preeklampsi berat, disamping itu juga kondisi awal pada penelitian ini jumlah trombosit antara kelompok perlakuan dan kelompok kontrol terdapat perbedaan yang bermakna dengan $P$ value 0,001 . Kemungkinan lain adalah waktu penelitian yang relatif pendek (2 minggu).

\section{KESIMPULAN}

1. Pemberian kapsul ekstrak garlik selama 2 minggu pada preeklampsi ringan memberikan pengaruh yang bermakna pada penurunan tekanan sistole dan diastole dibandingkan dengan kontrol.

2. Pemberian kapsul ekstrak garlik selama 2 minggu pada preeklampsi ringan tidak berpengaruh bermakna terhadap perubahan jumlah trombosit dibandingkan dengan kontrol.

\section{SARAN}

1. Diperlukan penelitian lebih lanjut dengan waktu lebih panjang untuk menilai outcome bayi

2. Untuk menilai lebih akurat efek kapsul ekstrak garlik diperlukan penelitian dose dependent dengan lebih dari satu dosis pada kelompok perlakuan dan jumlah sampel lebih banyak.

\section{DAFTAR KEPUSTAKAAN}

1. Dekker GA, Sibai BM. Etiology and Pathogenesis of Preeclamsia: Cureent concept. Am J Obstet Gynecol 1998; 179: $1275-1278$.

2. Mose JC. Prevention of Preeclamsia. Surabaya: The Scientific Meeting On Fetomaternal Medicine; 2002.

3. Angsar MD. EPH Gestosis Dalam Prespektiv. Surabaya: UPF Obstetri \& Ginekologi Fak. Kedokteran Universitas Airlangga RSUD Dr. Sutomo.

4. Angsar D, Simanjuntak P, Handaya, Sjahid S. Satgas Gestosis POGI KOGI VI Ujung Pandang; 1985.

5. Jesse J, Mohseni M, Shah. Medical Attributes of Allium Sativum-garlic. http://wilkes.edu/kklemow/allium.html

6. Meizia D. Comparison of Nitric Oxide Serum Level And Platelet Count In Mild Preeklamsia Before And After Garlic (Allium Sativum) Treatment And Its Corellation With Blood Pressure. Fakultas Kedokteran Universitas Padjajaran Bandung:Thesis; 2000.

7. Soranna D, Hirani J, Das I. Garlic and Pregnancy. http://www.mistral.co.uk/garlic/preg.htm

8. Soranna D, Hirani J, Khan N, Das I. Garlic and Nitric Oxide Metabolism: The Implication During Pregnancy In http://www.mistral.co.uk/garlic/g and no.htm

9. Siegal G, Casper U, Walter A. Changes in Vascular Tone And Calcium Metabolism. http://www.garweb@mistral.co.uk

10. Neil A, Silagy C. A Meta Analysis of The Effect of Garlic on Blood Pressure and Serum Lipids. http://www3.mistral.co.uk/garlic/metaanal.htm

11. Kemper KJ. Clinician Information Summary: Garlic, in http://www.mcp.edu/herbal/default.htm.

12. Therapeutic use of garlic in http://www.carolnored.mybravenet.com/Monograph/GARLIC/garlic.HTM

13. Rahman K, Billington D. Dietery Supplementation with Aged Garlic Extract Inhibits Adp-Induced Platelet Agregation In Human. Jounal of Nutrition; 2000; 130: 2662-2665.

14. Lawson LD, Ransom DK, Hughes BG. Inhibition of Whole Blood Platelet-Agregation Bay Compounds In Garlic Clove Extract And Comercial Garlic Powder Product. Thromb Res; 1992; 65: 141-156.

15. Ryu K, Ide N, Matsura H, Itakura Y. Na-(1-Deoxy-d-fruktosa)-L-Arginine, an Antioksidan Compound Identified In Aged Garlic Exstract. Jornal of Nutrition 2001; 131: 972S-976S. 